\title{
Zagadnienie wojny sprawiedliwej w polskiej literaturze prawnej XV i XVI wieku
}

Tadeusz Marian Nowak 
nAPIS Seria VII 2001

\section{Tadeusz Marian Nowak}

\section{Zagadnienie wojny sprawiedliwej w polskiej literaturze prawnej XV i XVI wieku}

$\mathrm{P}$ roblem wojny sprawiedliwej pojawia się już w literaturze starożytnej, jednak bliższe czasom omawianym w niniejszym tekście są europejskie prace powstałe w średniowieczu. Znawca prawa międzynarodowego i jego historii, lwowski profesor Ludwik Ehrlich, którego wykładów słuchałem na Uniwersytecie Jagiellońskim po 1945 roku, w swej znakomitej, wydanej w 1955 roku pracy o powstałym w XV wieku polskim wykładzie prawa wojny, omówił wcześniejsze, średniowieczne traktaty poświęcone temu zagadnieniu, a wśród nich pochodzącą z XIII wieku Summę katalońskiego dominikanina Romualda z Penjafort i glossę do niej autorstwa francuskiego dominikanina Wilhelma z Rennes, a następnie fragment powstałej około 1269 roku drugiej części Sumıny teologicznej Tomasza z Akwinu oraz napisaną w 1360 roku rozprawę Jana de Lignano De bello, de represaliis et de duello ${ }^{1}$.

W Polsce na początku XV wieku powstała sytuacja, która spowodowała pojawienie się u nas pierwszych traktatów naukowych poświęconych zagadnieniu wojny sprawiedliwej. Były to czasy, kiedy państwo polskie, zjednoczone po okresie rozbicia dzielnicowego i wzmocnione wewnętrznie dzięki reformom przeprowadzonym za panowania Kazimierza Wielkiego, mogło się pokusić o odzyskanie ziem wydartych mu przed stu laty przez zaborczy zakon krzyżacki. Szanse powodzenia tego przedsięwzięcia bardzo poważnie zwiększało zawarcie - popartego unią personalną - przymierza z Litwą, która była również nieustannie atakowana przez Krzyżaków, występujących w tym wypadku - podobnie jak uprzednio przy podbijaniu ziem Prusów — pod hasłem nawracania pogan.

Natomiast niemałą trudność na drodze do odzyskania utraconych ziem stanowily zakorzenione wówczas w chrześcijańskich krajach Europy, w tym również częściowo i w Polsce, poglądy

' Zob. L. Ehrlich, Polski uyktad prawa wojry XV wieku. Kazanie Stanistawa ze Skarbimierza „De bellis iustis”, Warszawa 1955 , s. 80 . 
potępiające z moralno-religijnego punktu widzenia zarówno wojnę toczoną pomiędzy państwami chrześcijańskimi - a zwłaszcza zbrojne wystąpienie przeciwko państwu zakonnemu - jak i przymierze chrześcijańskiego władcy z poganami. Ażeby trudność tę pokonać, albo przynajmniej działanie jej złagodzić, należało udowodnić, że poglądy te są fałszywe.

Podjał się tego zadania prawnik i teolog Stanisław ze Skarbimierza ${ }^{2}$ (rok urodzenia nieznany, zmarł w 1431 roku), pierwszy rektor odnowionej w 1400 roku Akademii Krakowskiej, mieszczanin z pochodzenia, który kształcil się — prawdopodobnie na koszt królowej Jadwigi — w latach 1382-1396 na uniwersytecie w Pradze, gdzie uzyskał stopień doktora praw, a następnie wykładał na Akademii Krakowskiej prawo kanoniczne, zyskując sławę wybitnego mówcy i kaznodziei. Powierzano mu również misje o znaczeniu państwowym - między innymi przewodnictwo delegacji polskiej w czasie procesu z Krzyżakami w 1423 roku $^{3}$.

Opracowany przez Stanisława ze Skarbimierza traktat naukowy miał — zgodnie z ówczesnymi zwyczajami - formę kazania napisanego w języku lacińskim. Zachowało się kilka rękopisów tego traktatu, zatytułowanych De bello iusto et iniusto lub De bellis iustis. Rękopisy te nie są datowane, wszystko jednak wskazuje na to, że traktat powstał i został wygłoszony w pierwszej połowie 1410 roku, w okresie wojskowych i dyplomatycznych przygotowań do wojny z zakonem krzyżackim ${ }^{4}$.

Systematycznie ułożona treść traktatu Stanisława ze Skarbimierza obejmuje wszystkie istotne dla prowadzenia tej wojny przez Polskę — zagadnienia typu moralnego, chociaż ani Polska, ani Zakon nie są $\mathrm{w}$ traktacie wymienione. Najważniejsze zawarte $\mathrm{w}$ nim i udowodnione w stosowany wówczas sposób - twierdzenia mówią, że:

1. Istnieją dwa rodzaje wojen - sprawiedliwe i niesprawiedliwe. Za sprawiedliwe należy uznać tylko te wojny, które są toczone w obronie ojczyzny lub w celu odzyskania utraconych ziem - niezależnie od tego, ile czasu upłynęło od ich utracenia - a także dla uzyskania słusznego pokoju. Niesprawiedliwe są wojny mające na celu zagrabienie cudzego mienia lub terytorium.

2. Sprawiedliwą wojnę mogą toczyć tylko osoby świeckie. Osoby duchowne nie powinny w ogóle brać udziału w wojnach.

3. Każdy człowiek, posiadający władzę nad innymi, powinien zdawać sobie sprawę z różnic pomiędzy wojną sprawiedliwą i niesprawiedliwą. Nie powinien również rozpoczynać wojny przeciwko swym poddanym, dopóki oni uznają jego władzę.

2 Obecnie Skalbmierz w województwie świętokrzyskim.

${ }^{3}$ O Stanisławie ze Skarbimierza zob. Bibliografia literatury polskiej „Nowy Korbut”, t. 3, opr. R. Pollak z zesp., Warszawa 1965, s. 234-236; L. Ehrlich, Pawet Whodkowic i Stanistaw ze Skarbimierza, Warszawa 1954; J. Bardach, Historia państwa i prawa Polski, t. 1: Do polowy XV wieku, Warszawa 1964, s. 432-433; Historia nauki polskiej, t. 1, Warszawa 1970, s. 141; ibidem, t. 6, Warszawa 1974, s. 639-640.

${ }^{4}$ Krytyczne wydanie kazania Stanisława ze Skarbimierza, zawierające obszenny wstęp, edycję tekstu łacińskiego i tlumaczenia polskiego oraz komentarz: L. Ehrlich, Polski wyklad prawa wojny..., op. cit.; ibidem, s. 147-165, fotokopia rękopisu Bibliotcki Zakładu Narodowego im. Ossolińskich we Wrocławiu (dalej: BOss.), sygn. 818/II (podstawy edycji) oraz rozprawa Z. Budkowej (s. 215-220) o rękopisach kazania De bellis iustis i ich datowaniu. Z późnicjszych prac zob.: C. Zawodzińska, Pisma Stanistawa ze Skarbimierza, pierwszego rektora Uniwersytetu w kodeksach Biblioteki Jagiellońskiej, „Roczniki Biblioteczne”, t. 6, 1960, s. 299-327; R. M. Zawadzki, Spuścizna pisarska Stanistawa ze Skarbimierza. Studium źródtoznawcze, Kraków 1980. 
4. Prowadzący wojnę sprawiedliwą nie ponosi odpowiedzialności za śmierć i zniszczenia, dokonane na szkodę przeciwnika i własnych poddanych, w toku tej wojny.

5. Wojny sprawiedliwe mogą być prowadzone nie tylko przeciw poganom, lecz również przeciw chrześcijanom.

6. Władca katolicki ma prawo wezwać na pomoc - jeśli jest to konieczne - pogan przeciwko chrześcijanom, wyrządzającym mu niesprawiedliwie szkody lub szukającym jego zguby.

7. Ani papież, ani władcy chrześcijańscy nie mają prawa najeżdżać krajów pogan, ani zajmować ich terytoriów.

8. W sprawiedliwej wojnie każdy żołnierz powinien mężnie stawiać czoło nieprzyjacielowi, „albowiem lepiej jest, aby zginął mężnie na wojnie, niż aby widział nieszczęście swego narodu i swoich"5.

9. Żołnierz, biorący udział w sprawiedliwej wojnie, ma obowiązek wykonywać rozkazy i stosować się do zakazów swego władcy.

Treść traktatu Stanisława ze Skarbimierza jest, jak widać, ściśle związana z potrzebami polskiej polityki zagranicznej i wewnętrznej w przededniu kampanii grunwaldzkiej, a równocześnie zawiera zasady o wartości nieprzemijającej, stanowiące do dziś podstawę koncepcji wojen sprawiedliwych.

Bitwa pod Grunwaldem, stoczona 15 lipca 1410 roku, złamała militarną potęgę zakonu krzyżackiego, jednak dalsze wydarzenia tej wojny spowodowały, że kończący ją pokój, zawarty 1 lutego 1411 roku w Toruniu, nie zwracał Polsce zagrabionego przez Krzyżaków w 1309 roku Pomorza Gdańskiego, którego odzyskanie było dla Polski głównym celem wojny. Równocześnie jednak Zakon nie potrafił w pełni odbudować swych sił ekonomicznych i wojskowych, zwłaszcza że już w lipcu 1414 roku doszło do ponownej wojny z Polską i Litwą. Nie odnosząc sukcesów na polu walki, Krzyżacy tym usilniej rozwijali akcję propagandową, mającą przekonać papieża, cesarza oraz wladców i sfery rządzące w krajach zachodnioeuropejskich, że Polska i sprzymierzona z nią, według nich ciągle jeszcze pogańska, Litwa nękają Zakon powtarzającymi się najazdami, chcąc mu wydrzeć nadane przez papieży i cesarzy ziemie.

Wydarzeniem międzynarodowym wielkiej wagi był w tym czasie, zwołany w 1414 roku do Konstancji i trwający aż do 1418 roku, sobór powszechny. Jego zasadniczymi celami były: przywrócenie jedności Kościoła katolickiego, mającego wówczas aż trzech równocześnie działających papieży, potępienie herezji w postaci nauk Anglika Jana Wiklefa i Czecha Jana Husa oraz usunięcie nadużyć, szerzących się w kurii papieskiej i wśród kleru. O znaczeniu i związanym z tym znacznym zakresie oddziaływania soboru świadczy fakt, że wzięło w nim udział 890 dostojników kościelnych i świeckich, 20000 księży i zakonników, 1560 rycerzy i 2000 delegatów z 37 uniwersytetów. Było to forum ogromne, obejmujące reprezentantów wszystkich krajów katolickich i dające przez to wielkie możliwości uprawiania na nim propagandy politycznej. Tak też chcieli wykorzystać sobór Krzyżacy, wysyłając nań przedstawicielstwo z Janem Wallenrodem jako przewodniczącym i Piotrem z Ornety jako głównym rzecznikiem Zakonu. Wkrótce też

\footnotetext{
${ }^{5}$ L. Ehrlich, Polski wyklad prawa wojny..., op. cit., s. 140-143: „quoniam melius est virtuose eum mori in bello, quam videre mala gentis sue et suorum".
} 
przybyło do Konstancji poselstwo polskie pod przewodnictwem arcybiskupa gnieźnieńskiego Mikołaja Trąby. W jego skład wchodził, jako główny rzecznik polski w randze ambasadora, uczony prawnik, rektor Akademii Krakowskiej Paweł Włodkowic. Urodzony około 1370 roku we wsi Brudzeń nad Skrwą w ziemi dobrzyńskiej ${ }^{6}$, w szlacheckiej rodzinie herbu Dołęga, zmarł w Krakowie po 1435 roku. Studiował w latach 1387-1397 na uniwersytecie w Pradze, a następnie w latach 1404-1408 w Padwie. Doktorat uzyskał w Krakowie na przełomie lat 1411 i 1412 . W tym też czasie otrzymał kościelną godność kanonika katedry krakowskiej i uniwersytecką — profesora Akademii Krakowskiej ${ }^{7}$.

Głównym zadaniem Pawła Włodkowica na soborze było przeciwstawienie się wrogiej Polsce propagandzie krzyżackiej. Nie chodziło tu jednak o wystąpienie typu sądowego, lecz o postawienie sprawy na płaszczyźnie rozważań teoretycznych, odpowiadających charakterowi soboru. Wpłynęło to na sposób ujęcia napisanych przez Włodkowica prac, przedstawionych w czasie soboru w Konstancji ${ }^{8}$. Pierwsza z nich, mówiąca o władzy papieża i cesarza w stosunku do pogan ${ }^{9}$, została rozpowszechniona wśród uczestników soboru 5 lipca 1415 roku. Dzieło to, zachowane w kilku rękopisach, składa się z trzech części. Pierwsza zawiera wstęp historyczny, przedstawiający dzieje zakonu krzyżackiego, jego przybycie do Polski, podbój ziem Prusów, uzyskanie od papieża i cesarza dokumentów nadających mu zdobyte ziemie, a wreszcie bezprzykładnego postępowania Zakonu w stosunku do Polski i Litwy. Krzyżacy bowiem Polaków:

...swych fundatorów, srodze napadają, biorą do niewoli swoich dobroczyńców, zwołując sobie na pomoc duży zastęp chrześcijan, jakby na wyprawę przeciw niewiernym (...) skierowują armię przeciw katolickiemu królowi Polski. Najeżdżają Królestwo Polskie, równają z ziemią grody, inne obracają w perzynę, łupią, gwałcą i wyrządzają tam przeliczne niegodziwości.

(Pisma, I, 4-5)

Ponadto, po przyjęciu przez Litwinów chrztu

...Krzyżacy jakby zmartwieni, że w ten sposób utracili okazję zajmowania ich ziem (...) z jeszcze większą zaciekłością najeżdżają raz po raz, według swego zwyczaju, nowo nawróconych (...) wielu okrutnie zabijają, palą ich nowe kościoły i niezliczone inne czynią bezeceństwa.

(Pisma, I, 4)

${ }^{6}$ Obccnie w wojcwództwie mazowieckim.

7 O Pawle Włodkowicu zob. Bibliografia literatury polskiej „Nowy Korbut”, op. cit., s. 407-410; L. Ehrlich, Pau'et Wtodkowic..., op. cit.; idem, Rektor Pawet Wodkowric — rzecznik obrony przeciw Krzyżakom, Kraków 1963; T. Brzostowski, Pawet Wlodkowic, Warszawa 1954; J. Bardach, op. cit., s. 432-434.

${ }^{8}$ Krytyczne wydanie pism Pawła Włodkowica, zawierające obszerny wstęp, edycję tekstu łacińskicgo i tłumaczeń polskiego i angiclskiego oraz komentarz, opracował L. Ehrlich (Pisma wybrane..., t. 1-3, Warszawa 1966, 1968,1969 [dalcj: Pisma, z numeracją tomu i paginacją w nawiasach]). Rçkopisy intcresujących nas tu pism Pawła Włodkowica (przywoływanych zwyczajowo za pomocą incipitów), znajdujące siç obecnic w BOss. (sygn. 166) oraz w Bibliotece Czartoryskich w Krakowic (sygn. 232) wydał M. Bobrzyński w: Starodawne praw'a polskiego pomniki, t. 5, Kraków 1878, s. 161-194, 234-236, a ostatnio L. Ehrlich w: Pisma, t. 1 i 2.

9 Zob. Pisma, t. 1, s. 27-112: Saevientibus. 
Druga część tej pracy Włodkowica poświęcona jest udowodnieniu, że papież nie ma prawa pozbawiać pogan ich ziem, a może jedynie żądać, aby wpuścili do kraju misjonarzy, którym z kolei nie wolno zmuszać pogan do przyjęcia chrześcijaństwa. W trzeciej części pracy mowa jest o tym, że cesarz również nie ma prawa dysponowania ziemiami pogan, w związku z czym dokumenty cesarskie, nadające Krzyżakom ziemie Prusów, są bezwartościowe. Ponadto Włodkowic ostro potępia prowadzone przez Krzyżaków wojny jako niesprawiedliwe, określając przy tym sześć warunków, które musi spełniać wojna, ażeby można ją było uznać za sprawiedliwą. Najważniejsze z nich — świecki charakter ludzi prowadzących wojnę, dążenie do odzyskania dóbr lub konieczność obrony ojczyzny jako przyczyna wojny, a zawarcie słusznego pokoju jako jej cel — pokrywaja się z warunkami wysuwanymi nieco wcześniej przez Stanisława ze Skarbimierza.

Następnego dnia, 6 lipca 1415 roku, Paweł Włodkowic przedstawił swoje poglądy na powyższe tematy na plenarnej sesji soboru, ujmując je w 52 „konkluzjach”10.

Sobór rozpatrzył sprawę sporu polsko-krzyżackiego jednak dopiero znacznie później, na sesji, która odbyła się 13 lutego 1416 roku. Na sesji tej strona polska przedstawiła swoje oskarżenie. Towarzyszył mu obszerny memoriał Pawła Włodkowica ${ }^{11}$, szczegółowo uzasadniający zarzuty wysunięte przeciw Krzyżakom. Odpowiedzią na te pisma były traktaty Jana Frebacha z Bambergi i dominikanina $z$ terenu państwa krzyżackiego Jana Falkenberga, autora wcześniejszego paszkwilu na Polskę, w którym pisał, że Polacy i ich król są „nienawistnymi heretykami” i „bezwstydnymi psami”, którzy wrócili do pogaństwa i których „władcy świeccy winni przy pomocy sił zbrojnych wytracić"12.

Paweł Włodkowic odpowiedział na enuncjacje Jana z Bambergi i Jana Falkenberga, zawierając swoją replikę w traktacie mówiącym o zakonie krzyżackim i o wojnie toczonej przez Polaków przeciwko niemu ${ }^{13}$. Praca ta złożona jest $z$ dwóch części. W pierwszej autor charakteryzuje zakon krzyżacki i metody jego postępowania, posługując się argumentacją znaną nam już z poprzednich jego pism, a w drugiej uzasadnia tezę mówiącą, że Krzyżacy toczyli niesprawiedliwe wojny przeciw poganom. Polska natomiast miała pełne prawo do korzystania z pomocy pogan w sprawiedliwej, obronnej, mającej na celu odzyskanie utraconych ziem wojnie przeciwko Krzyżakom.

Sobór w Konstancji nie rozstrzygnął sporu polsko-krzyżackiego, jednak działalność Pawła Włodkowica pozostawiła trwałe ślady. Zachwiała wiarę zachodniej Europy w słuszność postępowania Krzyżaków i przyczyniła się do dokładniejszego sprecyzowania pojęcia wojen sprawiedliwych.

Polskim pisarzem, który w XVI wieku wszechstronnie przedstawił zagadnienie wojen z wyraźnym określeniem swojego stosunku do problematyki wojen sprawiedliwych, byl Andrzej Frycz Modrzewski (ok. 1503-1572) ${ }^{14}$, który poświęcił tym sprawom całą trzecia księgę dzieła Commentariorum de Republica emendanda libri quinque, wydanego po raz pierwszy w Krakowie w 1551 roku

\footnotetext{
10 Zob. ibidem, s. 113-143: Opinio Ostensis.

11 Zob. ibidem, t. 1, s. 144-271; t. 2, s. 182-215: Ad aperiendam.

12 Tekst paszkwilu Falkenberga przytacza J. Długosz, Historiae Polonicae libri XII, t. 4, Kraków 1863, s. 211-214; por. Rozbiórkrytyczny Annalium Poloniae Jana Dlugosza z lat 1335-1444, t. 1, Wrocław 1961, s. 173-176. Odnośnc tcksty brzmią: „Quod Poloni et eorum rex sunt odibiles haeretici et impudici canes, reversi ad vomitum suae infidelitatis”; "Quod principes saeculi tenentur sacrilegos exercitibus Polonos et eorum regem de terra pergere".

13 Zob. Pisma, t. 2, s. 216-409: Quoniam error.

14 O Andrzeju Fryczu Modrzewskim zob. Bibliografia literatury polskiej „Nowy Korbut”, op. cit., t. 2, Warszawa 1961, s. 160-172; wydanic naukowe dzicł: Opera onnia, t. 1-5, wyd. K. Kumaniccki, Warszawa 1953-1960; tł. na język polski: Dzieła wszystkie, t. 1-5, tł. E. Jędrkiewicz, L. Joachimowicz [i in.], Warszawa 1953-1959, Indeks, opr. J. Pclc, Warszawa 1960.
} 
(bez księgi czwartej i piątej), a następnie w Bazylei w roku 1554 (w całości) oraz w (znów niepełnym) tłumaczeniu polskim Cypriana Bazylika w Łosku w 1577 roku. W księdze tej, zatytułowanej O wojnie ${ }^{15}$, Modrzewski wyraża między innymi pogląd, że wojna przynosi ludziom tak wielkie cierpienia, iż można się na nią godzić jedynie wtedy, gdy jest nieunikniona i gdy ma sprawiedliwy charakter. Określa przy tym, że wojnę można uznać za sprawiedliwą tylko wtedy, gdy ma charakter obronny i toczy się po wyczerpaniu wszystkich środków pokojowego rozstrzygnięcia sporu. Równocześnie zdecydowanie potępia wojnę niesprawiedliwą, podejmowaną nieraz przez władców dla zdobycia sławy lub rozszerzenia terytorium swego państwa. Modrzewski wyraża też opinię w sprawie przyjaźni i sojuszy między państwami, rozszerzając je również na stosunki między państwami chrześcijańskimi i niechrześcijańskimi. W warunkach polskich chodzić tu mogło przede wszystkim o Turcję i Tatarów.

Zasadniczą idę̨ w sprawie konfliktów zbrojnych zawarł Frycz Modrzewski w stale aktualnym zdaniu:

A iżby wojny wieść nigdy nie było potrzeba, przeto pokój najwięcej, ile być może, ze wszytkimi ludźmi postronnymi ma być zachowan.

${ }^{15}$ Zob. A. Frycz Modrzewski, Dzieła wszystkie, op. cit., t. 1: O poprawie Rzeczypospolitej, tł. E. Jędrkiewicz, Warszawa 1953, ks. III: O wojnie, s. 302 i n. 